\title{
TÉRBELI ÖSSZEFÜGGÉSEK VIZSGÁLATA PAKS ÉS KALOCSA GRAVITÁCIÓS ZÓNÁJÁBAN
}

INVESTIGATION OF SPATIAL RELATIONSHIPS IN THE GRAVITY ZONE OF PAKS AND KALOCSA

\author{
Káposzta József ${ }^{1}$, Lőrinc Balázs ${ }^{2}$, Urbánné Malomsoki Mónika ${ }^{3}$ \\ egyetemi tanár ${ }^{1}$, egyetemi hallgató ${ }^{2}$, tanszéki mérnök ${ }^{3}$ \\ Szent István Egyetem, Gazdaság- és Társadalomtudományi Kar ${ }^{1,2,3}$ \\ E-mail: kaposzta.jozsef@gtk.szie.hu1, lorincbalazs97@gmail.com², \\ urbanne.malomsoki.monika@szie.hu ${ }^{3}$
}

\section{Összefoglalás}

A Paks és vonzáskörzetében zajló jelenlegi, illetve tervezett, jövőbeli fejlesztések mind a helyi társadalom, mind a gazdaság, mind pedig az infrastruktúra fejlődése szempontjából fontos tényezőként jelennek meg. Az országos szinten is magas prioritással bíró térségi fejlesztések az említett „alrendszerek” vizsgálatával válhatnak érthetővé, illetve átláthatóvá. A Kalocsai járás tekintetében - a „gravitációs zóna" részeként - megfogalmazható, hogy a Pakshoz való közelségnek a Duna határt szab, ami a munkaerő és egyéb javak áramlása, azaz - többek között - a mobilitás szempontjából hátrányként jelenik meg. A megépülő Duna híd lehet az első lépés a két gazdasági terület endogén forrásainak összekapcsolásához, amely a térségek szempontjából várhatóan gazdaságnövekedést generálhat.

\begin{abstract}
The current and planned enhancements - which are taking place at Paks and its agglomeration - are important factors either for the local society, the economy or the infrastructure. The area developments which own a high priority nationwide, could be understandable and transparent by the investigation of the mentioned sub-systems. In the case of the district of Kalocsa - as part of the "gravitational-zone" - we can formulate that the Danube circumscribe Paks from Kalocsa, which in the flow of labour and other goods - inter alia - can appear as a disadvantage in terms of the mobility. The Danube-bridge which is under construction, could be the first step in the conjuncture the endogeneous source of these two economical area, which may generate an economic growth.
\end{abstract}

Kulcsszavak: endogén források, gravitációs zóna, területfejlesztés, Paks, Kalocsa JEL besorolás: $R 10, R 11$

LCC: HD72-88

\section{Bevezetés}

A területfejlesztés egyik legfontosabb és legvitatottabb kategóriája a területi egyenlötlenség. A fogalom kiemelt szerepe elméleti szempontból abból ered, hogy a tér fogalma elválaszthatatlan az egyenlőtlenség fogalmától. A területi egyenlőtlenség értelmezése és tartalma egyben az egyik legvitatottabb területfejlesztési kérdés (Nemes Nagy, 1998). Véleményünk szerint hazánkra és az Európai Unió szinte teljes egészére egyaránt igaz, hogy jelentős fejlettségbeli különbségek vannak országhatárokon belüli és azokon túlnyúló területek között is.

Ebben a sokváltozós viszonyrendszerben, amelyet a területi egyenlőtlenségek és különbségek hoznak létre, az újszerủ fejlesztési stratégiák kidolgozását régiókon belüli lehetőségekre, így az 
endogén potenciálok kiaknázására, a saját és helyi erők megújítására, illetve fejlesztésére szükséges alapozni. Mindezek alapján sincs egységesen elfogadott megoldási keretrendszer a területi különbségek mérséklésére, amiért kiemelten fontos szemügyre venni az adott térségben uralkodó viszonyokat, erősségeket és gyengeségeket, illetve, ami nélkülözhetetlennek bizonyul e témakörben, az a természeti és a gazdasági tényezők mellett, a társadalmi folyamatok figyelembevétele (Horváth, 2004, Káposzta, 2014).

Egy másik megközelítésben - Faragó szerint - mindig is voltak és lesznek is társadalmi-területi különbségek. A térbeli, azaz a területi különbségek megléte és az egyenlötlen fejlődés alaptételként van jelen a mindennapokban. A tértudományok egyik alaptézise, hogy a fizikai különbözöség, illetve a gazdasági és társadalmi egyensúlytalanság bizonyul általános állapottá hazánkban és globálisan is. A teljes kiegyenlítődés elérését soha nem lehet elérni, ugyanis akár a szellemi javakat, akár a fizikai javakat vesszük vizsgálat alá mindig fognak némi különbözőséget mutatni (Faragó, 2016). A területi különbségek mélyülése akár hazánkban, de globálisan is tapasztalható jelenség, azokban a térségekben, ahol folyamatosan csökken a népesség száma (elvándorlás, elöregedö társadalom, elnéptelenedés), rohamosan csökken a lakosság képzettségi szintje, emellett csökkenő tendenciát mutat az infrastruktúra, romlik a természeti környezet egészsége, illetve ahol a térség kulturális és hagyományos öröksége elveszik (Horváth, 2004, Nemes Nagy, 2005, Nagy-Lendvay, 2018, Farkas et al. 2020).

A probléma megoldásának lehetséges irányai közé tartozik a leszakadás gazdasági és társadalmi tényezőinek vizsgálata és elemzése, majd a lokális fejlesztési irányok újragondolása. Emellett, többek között az endogén források tervezésbe történő bevonásának szorgalmazása, a speciális képzési struktúrák kidolgozása, a keresletorientált gazdaságfejlesztési stratégia kidolgozása, a célzott beruházások szorgalmazása, illetve az állami és uniós források allokációja (Káposzta, 2014, Tóth, 2018, Tóth-Oláh, 2019). A területi egyenlőtlenségek enyhítésének az alapvető célja a fennálló területi különbségek csökkentése, illetve a fejlödésben lemaradt térségek felzárkóztatása. A fejlesztés alapvető kérdései közé tartozik, hogy mely térségeket sorolunk az elmaradott kategóriába, és mit tekintünk elérendő fejlettségi szintnek. Miután a területi egyenlötlenségek szituációját sok tényező alakítja és formálja, ezért érdemes a legfontosabbakat külön is megvizsgálni és értelmezni a területi egyenlőtlenségekben betöltött szerepét. G. Fekete öt fő tényezőt nevez meg az egyenlőtlenség előidézői, illetve az elmaradottság tényezői között (G. Fekete 2006, Ritter, 2008, Ritter, 2010, Káposzta-Tóth, 2013). A centrum-periféria modell a gazdaság- és társadalomtudományokban elterjedt módszer, amely egy egyenlötlenségi rendszerként vázolható fel. E rendszerben a centrum és periféria között egyenlőtlen függőség áll fenn, ahol a centrum, központi szerepkört betöltve, befolyásoló és meghatározó szereppel bír a periféria felett (Barta, 1990, Nemes Nagy, 1990, Illés, 1997, Nagyné, 2013). Nemes Nagy szerint a centrumok és perifériák rendszerét a következő három jelentésben lehet értelmezni (Nemes Nagy, 1996):

- A földrajzi centrum-periféria rendszer magja a helyzeti megosztottsága a térelemeknek. Itt a matematika középpont-határ fogalompárral azonosítható az elmélet jelentése. A centrum itt jellemzően egy kitüntetett helyként definiálható, míg a periféria külső, peremi zónát jelent. E jelentésben a centrum az a pont, amely az adott térség többi pontjához összességében a legközelebb van, míg a perifériák a legtávolabbi pontok helyei. A centrális helyzetben lévő pontból általában a legkisebb ráfordítással érhetö el a térség összes többi pontja.

- A fejlettségi - gazdasági centrum periféria viszony középpontjában a gazdasági fejlettségi kettősség megosztó relációja áll. A földrajzi térre vetítve e viszonyt a centrumok a fejlett, a perifériák az elmaradott térségekkel azonosíthatók. E 
jelentéshez kapcsolható a centrumtérségek illetve a perifériák belső strukturális különbözősége, ami reagáló és megújulási képességeikre is hat.

- A hatalmi centrum-periféria viszony lényegét a két pólus között kimutatható függés, hatalmi, érdekérvényesítési egyensúlytalanság adja. Ebben a jelentésben a centrumperiféria viszonyhoz azt müködtető társadalmi mechanizmusok, intézmények kapcsolódnak.

A centrum-periféria modell mindhárom jelentésében többszintü kapcsolatot jelent. Az egy adott szinten centrumszerepet betöltő hely, gazdálkodó egység, társadalmi csoport intézmény egy más viszonyrendszerben periférikus is lehet. A helyzeti és a fejlettségi centrum-periféria viszonyrendszert az első táblázatban foglaltak szerint lehet megközelíteni. Az egyes térségtípusok hazai megjelenését - a jellemzőik szerint - e négy kategória alapján lehet osztályozni, miszerint egy régió funkcionálhat központi magként, belső perifériaként, dinamikus peremként, illetve külső perifériaként is (Nemes Nagy, 1996, Péli, 2013, PéliNeszmélyi, 2015).

A kutatási terület térbeli elhelyezését a 2015-ben létrehozott Paksi Társadalmi Tanács által történő, települési lehatárolás alapján határoztuk meg. Így a térséget három statisztikai járásra, illetve azok településeire határoltuk le: a Kalocsai-, a Paksi, illetve a Tolnai járás alkotta térségre, amit kiegészít a Szekszárdi járás települései közül maga Szekszárd városa és Szedres község, illetve, - a Kalocsai járás minden települése - Újsolt község is az elemzés részét képezi. Az említett Paksi Társadalmi Tanács, illetve testületének alapvető célja az atomerőmü körüli települések teljes körü támogatása, illetve lakosságuk tájékoztatása. A Társadalmi Tanácsot a települések polgármesterei alkotják, kiegészülve a térség parlamenti képviselőivel (Miniszterelnökség, 2015).

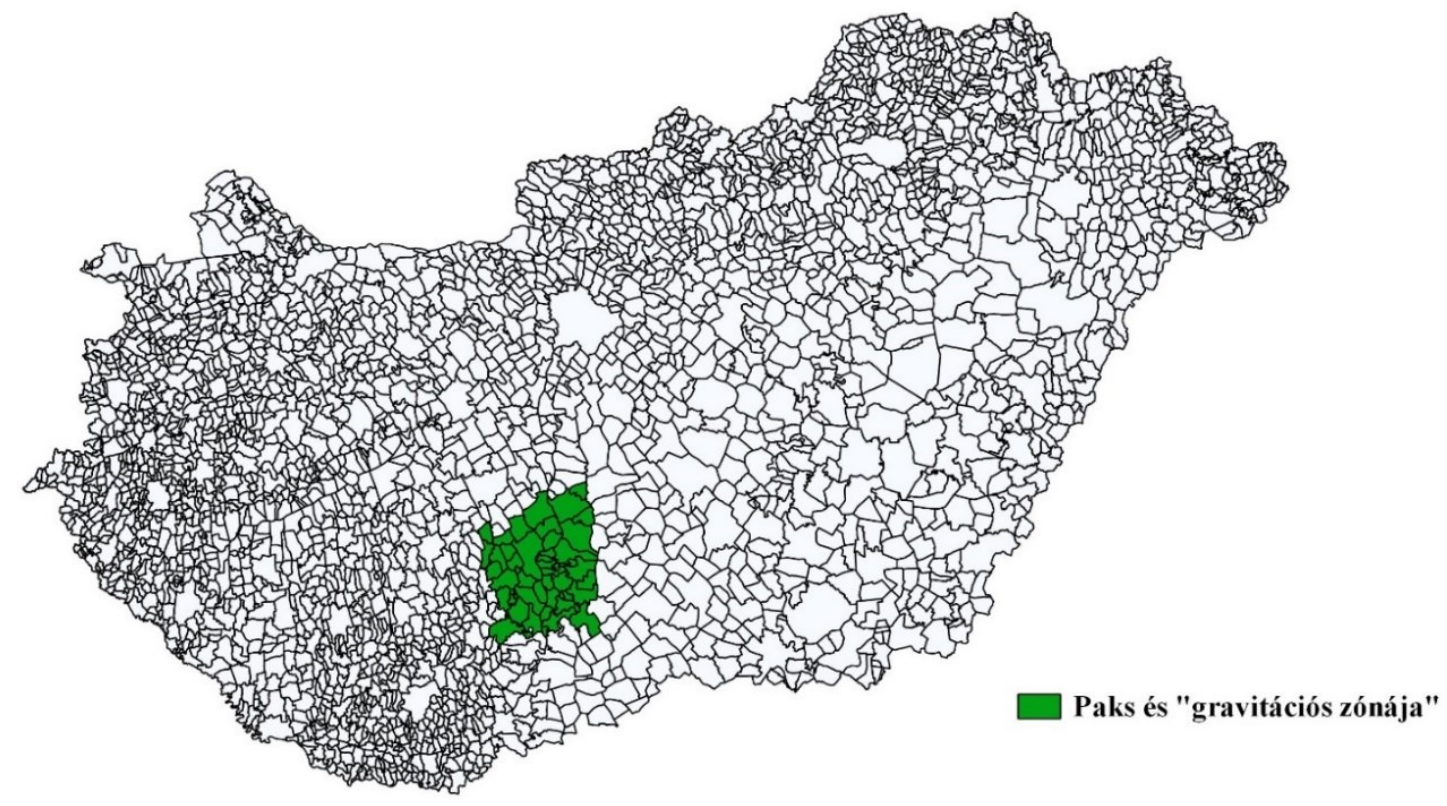

\section{1. ábra: A kutatási helyszín térbeli elhelyezése Magyarországon}

Forrás: (Saját szerkesztésü infógrafika, QGIS; 2019)

A lehatárolt területet a Duna kettészeli, amely a térség fejlődése szempontjából földrajzi hátrányként jelenik meg. A korábbiakban említett Paks-Kalocsa híd létesítése mindenképp előnyös lehet, miszerint az egymástól légvonalban 15 km-re fekvő két járásszékhelyi város, illetve vonzáskörzetükben elhelyezkedő települések közúton is közelebb kerülnének egymáshoz. Emellett a tranzitforgalom esetében is lényegesen lerövidülne az utazási időtartam 
Kelet-Nyugat irányban a Duna felett. A pontos területi lehatárolás, illetve a Duna általi kettéválasztás alapján Paks mellett szükségesnek éreztük, hogy Kalocsa városát is centrumként nevezzük meg.

\section{Anyag és módszer}

A kutatásunkban, szekunder adatgyüjtéssel az Országos Területfejlesztési és Területrendezési Információs Rendszer (TeIR) által szolgáltatott társadalmi-, gazdasági- és infrastrukturális adatbázisok statisztikai adatait elemeztük:

- A népességváltozás és a népsürüséget;

- A természetes szaporodás/fogyás mutatót;

- A tényleges szaporodás mutatót;

- Az öregedési index mutató alakulását;

- A bruttó hazai termék (GDP) számának változását;

- A munkanélküliségi rátát;

- Az egy lakosra jutó összes nettó jövedelmet;

- Az új építésü lakások számának változását a lakásállomány százalékában;

- Illetve a közmüolló arányának alakulását.

A felsorolt mutatókból történő elemzést az eddigi tapasztalataink, illetve szakmai szempontok alapján is alkalmasnak tartottuk, hogy általuk feltérképezzük Paks és „gravitációs zónájának” jelenlegi társadalmi, gazdasági és infrastrukturális helyzetét. A kutatás alkalmával idősoros adatok ábrázolásával, illetve bázis- és láncviszonyszámokkal kalkulálva elemeztük a térségbe tartozó településeket, ahol többek között segítségünkre volt az - említett - infógrafikák szerkesztésénél a QGIS térinformatikai- és térképszerkesztő program.

\section{Társadalmi mutatók „alrendszere”}

A társadalmi mutatók bemutatásánál demográfia elemzésekkel igyekeztünk átfogó képet nyújtani a Paks és „gravitációs zónájába” tartozó járásokról (LAU 1), illetve e járások településeiről (LAU 2), ahol sorra vettük a vizsgált időintervallumon belül az egyes népességváltozást prezentáló mutatószámokat. Ezen „alrendszer” véleményünk szerint meghatározó információkkal szolgálhat többek között a vizsgált térség innovációs képessége szempontjából meghatározó jelentőségü humánerőforrás-kapacitásról is.

A népesség, a népesedési folyamatok következtében folyamatosan változik, miszerint a területi elhelyezkedése folyton módosul, az összetétele változik, illetve a születések és halálozások és a vándorlások révén állandóan megújul. A népesedés folyamatai ugyanakkor sokoldalúan differenciáltak, amiért a népességi változások visszahatnak a népesedés folyamataira. A demográfia tárgykörében ezért központi helyet foglalnak el a népesedési folyamatok, ezzel együtt a természetes- és tényleges szaporodás és az öregedési mutató együttes vizsgálata. Véleményünk szerint az ezen alfejezet által taglalt társadalmi terület elemzés némileg túlhangsúlyozottnak tünhet, viszont, a gazdaság egyetlen aspektusa sem képzelhető el a humán tőke nélkül.

A 2000 és 2017 közötti időintervallumon belül elemeztük a vizsgált területegység népességszám változását - települési szinten - százalékban kifejezve, ahol bázis évnek az ezredfordulót vettük alapul. Általánosan elmondható, hogy népességcsökkenési tendencia mutatkozik népességszám-változási trendként a lehatárolt területegységen belül. A Paksi járás esetében tapasztalható csak népességnövekedés 2001-ben, a másik három járást, illetve 
településeit megvizsgálva folyamatos népességfogyásról beszélhetünk az ezredfordulótól egészen napjainkig. Az országosan is jellemző népességcsökkenési tendenciát mértani közép számítással hasonlítottuk össze a járási adatokkal. A járások tekintetében az átlagos népességváltozás $(-0,37)$ százalék, illetve $(-0,79)$ százalék közötti értékéket vesz fel a vizsgált intervallumon belül, ami alapján kijelenthető, hogy folyamatos népességcsökkenés mutatkozik a térségben. Az országos adatokat is figyelembe véve a 2000 és 2017 közötti időszakban átlagosan $(-0,19)$ százalékos népességcsökkenés az átlagos népességváltozás. Emellett szükségesnek éreztük megemlíteni, hogy népességszám alapján, 2017-ben, mind Kalocsa $(32,15 \%)$, mind Paks $(38,8 \%)$, mind Szekszárd $(55,55 \%)$ és mind Tolna $(61,82 \%)$ magas részét képzik a saját járásuk népességének, ezzel együtt a „gravitációs zónának” is, amely a városi pólus erősségét jelzi.

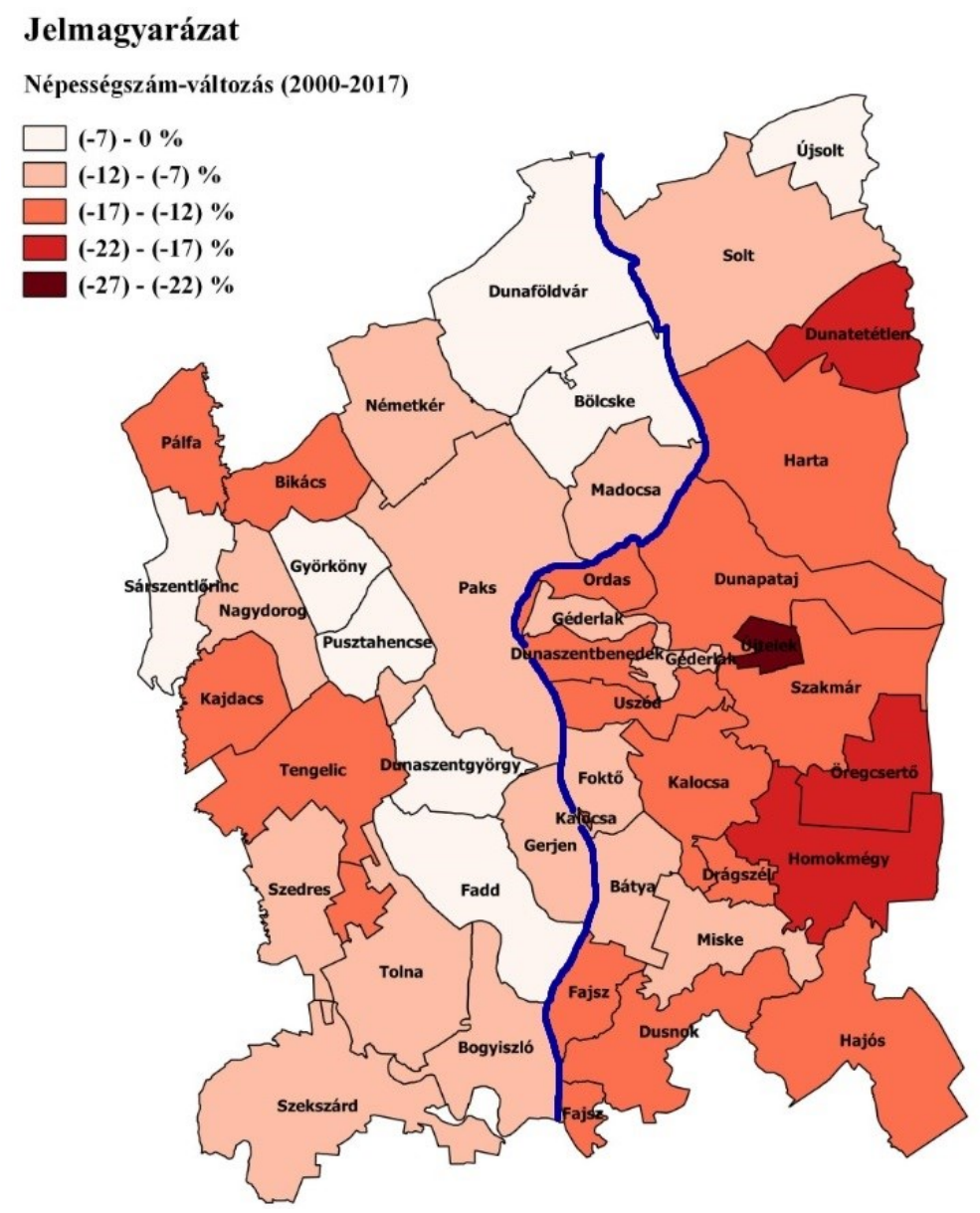

2. ábra: Paks és „gravitációs zónájának” népességszám-változása; 2000-2017 (százalék) Forrás: Országos Területfejlesztési és Területrendezési Információs Rendszer (TeIR) (Saját szerkesztésü infógrafika, QGIS; 2019)

A 2. ábrán a térség településeinek népességszám-változása látható. Az országos és járási adatokhoz hasonlóan, települési szinten is folyamatos népességcsökkenésröl beszélhetünk a vizsgált intervallumon belül. Kiugró értéket Újtelek, Dunatetétlen, Homokmégy és Öregcsertő esetében tapasztalni, ahol feltünően magas a népességfogyás. Az országos népességfogyási átlaghoz csupán Bölcske, Dunaföldvár, Dunaszentgyörgy, Fadd, Györköny, Pusztahencse, Sárszentlőrinc, illetve Újsolt adatai konvergálnak. Szembetünő viszont, hogy a téregység egészében dunántúli területen alacsonyabb a népességfogyási arányszáma, mint a Duna-Tisza közén. 


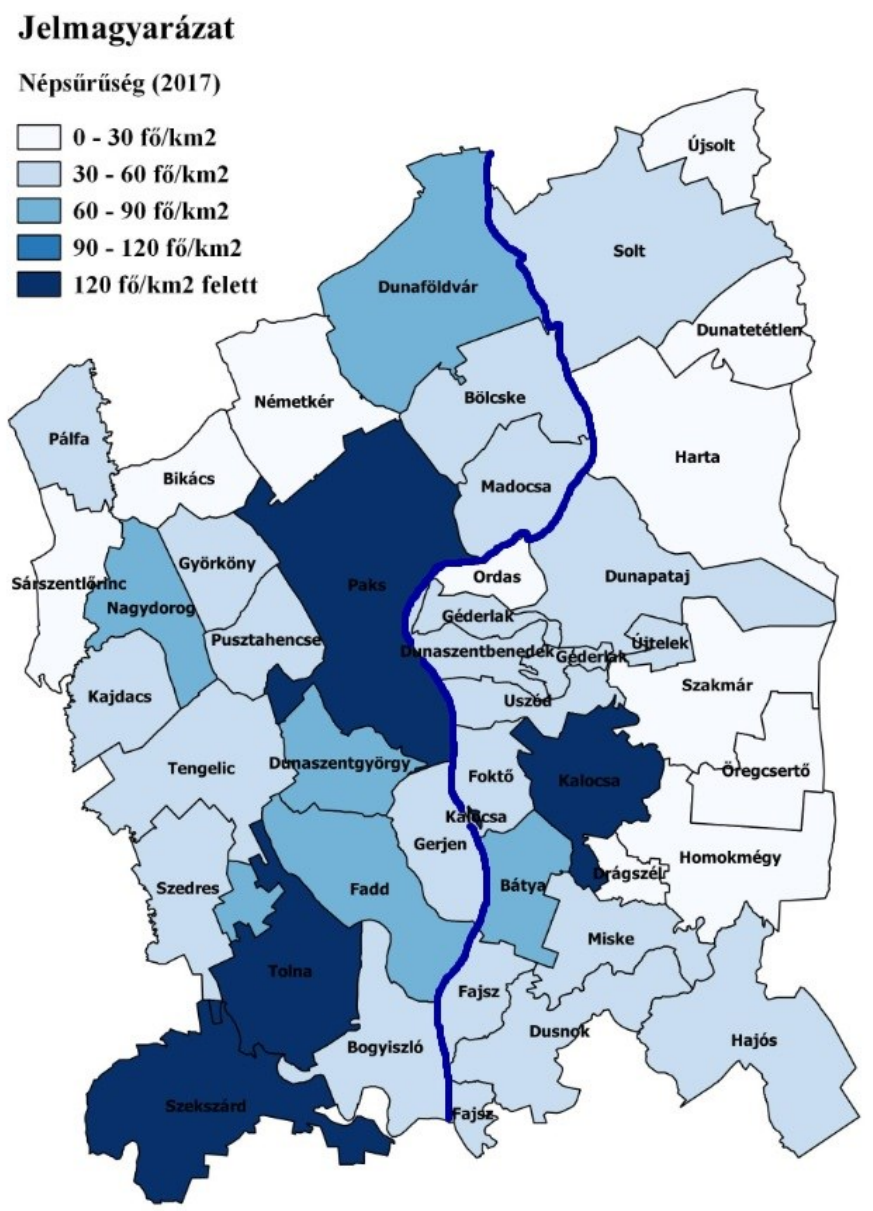

3. ábra: Paks és ,gravitációs zónájának” népsürüsége 2017-ben (fö/km2)

Forrás: Országos Területfejlesztési és Területrendezési Információs Rendszer (TeIR) (Saját szerkesztésü infógrafika, QGIS; 2019)

Az 3. ábrán a települések népsürüség szerinti besorolása kerül bemutatásra 2017-es adatok alapján. A népsürüség a településeken élő, állandó népességszám és a település területének $\left(\mathrm{km}^{2}\right)$ hányadosaként írható fel. A járásszékhelyi városok erősségét és súlyát jelzi ezen infógrafika, miszerint messze a legsürübben lakott települések halmazát alkotja Kalocsa, Paks, Tolna és Szekszárd. A népsürüség tekintetében kiugró értékek nem tapasztalhatóak a többi település tekintetében. A vidéki térségre jellemző adatokat olvashatunk le az ábráról a Duna mindkét oldalán. Továbbá az M6-os autópálya vonala is látható az ábrán, hiszen a régió dunántúli részén található, magas népsürüségü települések mentén fut (Dunaföldvár, Paks, Dunaszentgyörgy, Fadd, Tolna, Szekszárd).

A 4. ábrán a természetes szaporodás/fogyás mutató látható a 2017-es adatok alapján. Az élveszületések és a halálozások számának különbözetét ezer före vetítve írhatjuk fel e mutatót. Kiugróan magas természetes fogyásról Bikács, Hajós, Homokmégy, Dunatetétlen, Pálfa és Újsolt tekintetében beszélhetünk, ahol a természetes fogyás meghaladja a 12 ezreléket is. Így mutatva a térség ÉNY-i (Bikács, Pálfa), ÉK-i (Dunatetétlen, Újsolt), illetve DK-i (Hajós, Homokmégy) részeinek a problémás helyzetét. A lehatárolt területet összességében vizsgálva megállapítható, hogy szinte minden esetben természetes fogyás mutatkozik trendként, csupán Fadd, Uszód és Géderlak tekintetében fordul át pozitív tartományba a természetes szaporodás/fogyás mutató - felülmúlva az országos átlagot, amely 2017-ben (-4) ezreléket 
mutatott -, ezzel is kiemelve azt az országos problémát, hogy népességünk fogyó tendenciát produkál.

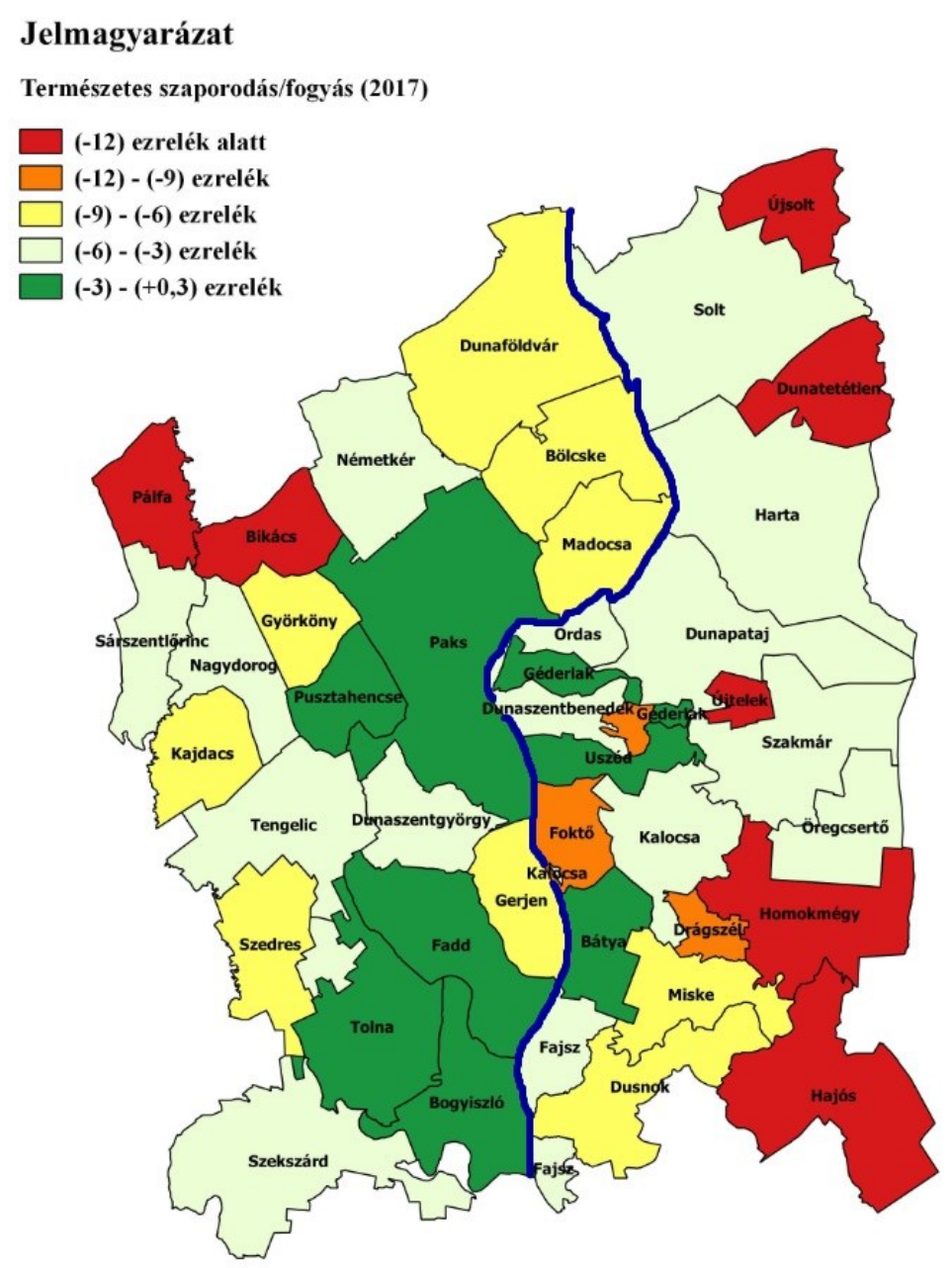

\section{4. ábra: A természetes szaporodás/fogyás mutató Paks és „gravitációs zónájában”, 2017- ben (ezrelék)}

Forrás: Országos Területfejlesztési és Területrendezési Információs Rendszer (TeIR) (Saját szerkesztésü infógrafika, QGIS; 2019)

A 5. ábrán az öregedési index változását mutatjuk be százalékpont változás alapján, a „gravitációs zóna” településeit érintve a 2000 és 2017 közötti időszakban, bázisviszonyszámokkal kalkulálva. Az ábra azt prezentálja, hogy 100 fő 0-14 éves korú egyénre hány fő 60 évesnél idősebb jut az adott mérési szinten. Az öregségi index ezáltal egy százalékos viszonyszámnak számít. Az öregségi index stagnálását a 100\%-os érték mutatja, amit jelen esetben egy település (Újsolt) ér el. A többi település tekintetében magasan kiugró értékeket mutat Dunapataj, Kalocsa, Ordas, Szedres, illetve Újtelek települések, ahol magasan több, mint duplájára emelkedett az idős korosztály, így a nyugdíjasok lélekszáma 2000-ről 2017-re. 


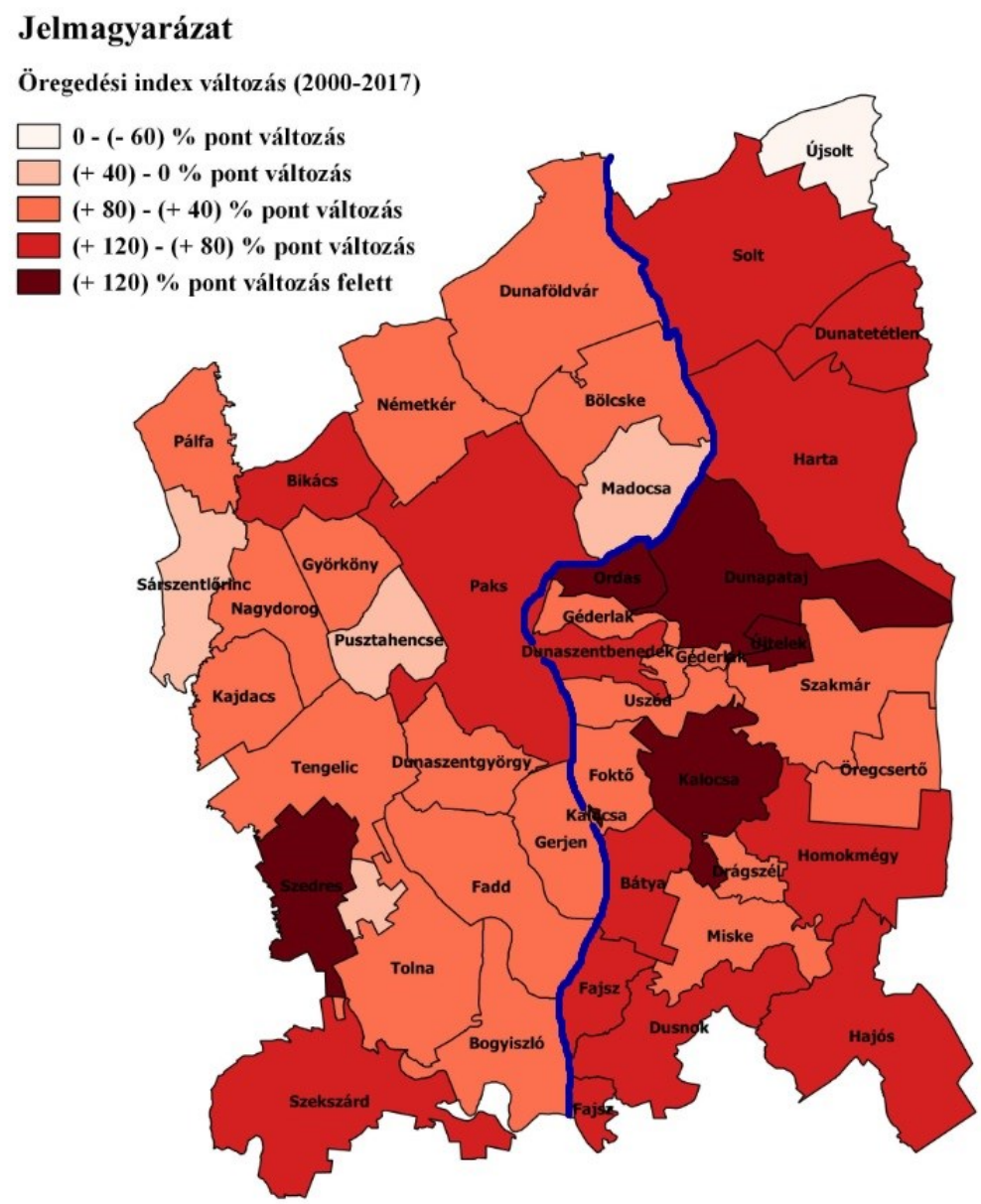

5. ábra: Az öregedési index mutató Paks és "gravitációs zónájában", 2017-ben (százalék)

Forrás: Országos Területfejlesztési és Területrendezési Információs Rendszer (TeIR)

(Saját szerkesztésü infógrafika, QGIS; 2019)

A térség problematikáját kiemelvén a Kalocsai járás települései esetében jóval magasabb az elöregedési arányszám, mint a vizsgált terület dunántúli részén.

\section{Gazdasági mutatók ,alrendszere”}

A Gazdasági mutatók ,alrendszerben” elemzésre kerül a bruttó hazai termék (GDP) változása, munkanélküliségi ráta alakulása, az egy lakosra jutó összes nettó jövedelem mértéke. Ezen alfejezet célja, hogy az említett gazdasági mutatók segítségével a térség gazdasági versenyképességét be tudjuk mutatni. Egyes mutatók esetében - településsoros adatok hiányában - csupán megyei (NUTS 3) és országos (NUTS 0) adatokat tudunk bemutatni. 


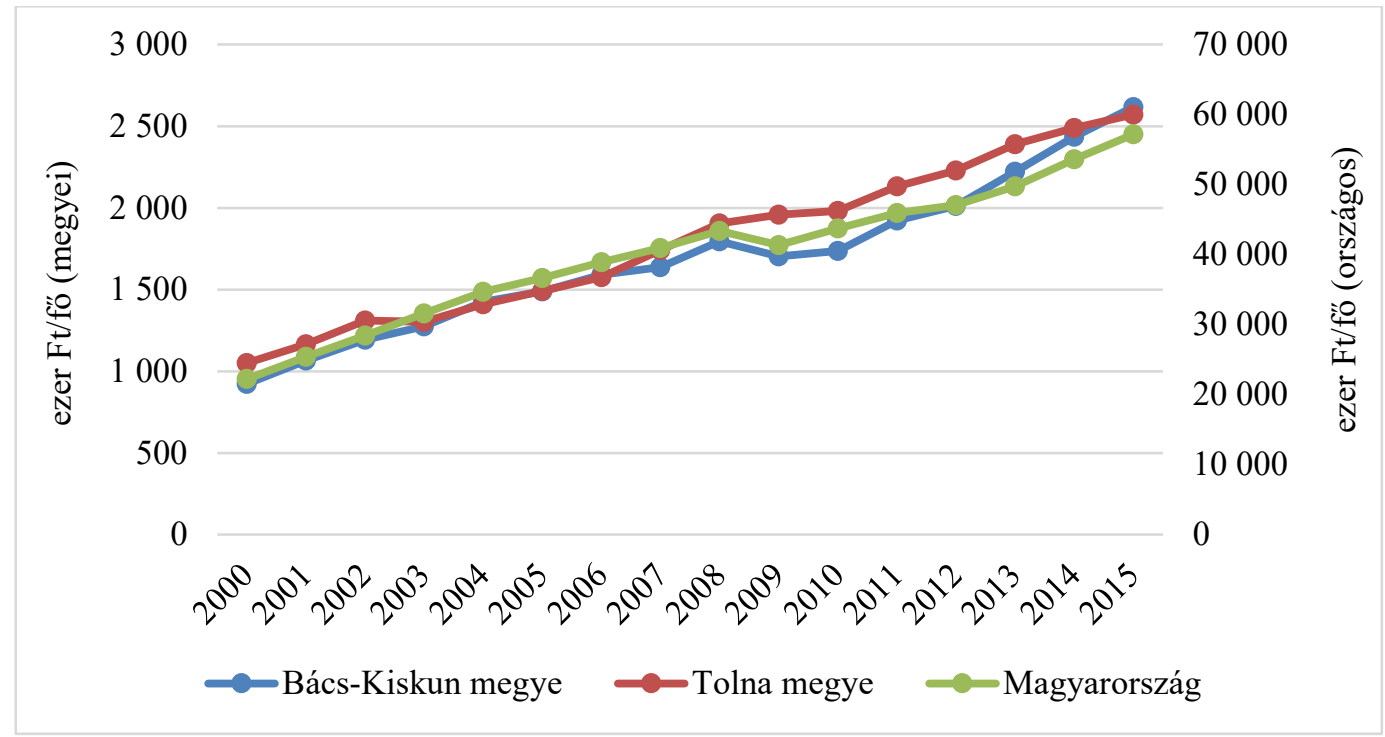

\section{6. ábra: Bruttó hazai termék (GDP) egy lakosra Bács-Kiskun megyében, Tolna megyében és Magyarországon; 2000-2015* (ezer Ft/fö)}

Forrás: Országos Területfejlesztési és Területrendezési Információs Rendszer (TeIR) (Saját szerkesztésü diagram, 2019)

A GDP egy földrajzi körülhatároláson alapuló fogalom, miszerint adott területen, adott idő alatt előállított, végső felhasználásra szánt javak (termékek és szolgáltatások) összességének értékét értjük a kifejezés alatt. A 6 . ábrán az említett bruttó hazai termék (GDP) változását mutatjuk be Bács-Kiskun megyében és Tolna megyében 2000 és 2015 között. Továbbá az említett változást másodlagos tengellyel szemléltetve, az országos adatokat is felvonultatjuk. A vizsgált intervallumon belül 2000-2008-ig folyamatos növekedés figyelhető meg az egyes területi egységek esetén, amely 2008-ban vélhetően a gazdasági válság következményeként recesszióba fordult, azaz visszaesés tapasztalható. A növekedési ütem viszont hasonló léptékekkel emelkedett mind a megyék, mind pedig az ország tekintetében 2011-től egészen a vizsgált intervallum végéig, amely érték napjainkig tovább emelkedik. A legfrissebb adatok alapján 2019-ben, az előző év azonos időszakához képest 4,9\%-kal nőtt országos szinten a gazdaság teljesítménye, ami magában foglalja a gazdasági növekedést, a foglalkoztatás növelését, a munkanélküliség csökkentését, illetve a bérek emelését is.

A közgazdaságtan megfogalmazása szerint a munkanélküliek és a foglalkoztatottak, vagyis a munkaerő piacán jelen lévők együttesen alkotják a munkaerö-állományt. Az ezredfordulótól egészen 2012-ig - a bázis évhez (2000) képest - növekedett a munkanélküliek aránya mind a négy járás tekintetében. Csúcsát a munkanélküliségi ráta 2009-ben érte a járások tekintetében, amit a gazdasági válság egyik hatásaként lehet megfogalmazni. A munkanélküliek számának látványos csökkenése 2013-tól kezdődött meg, amelyet a munkaalkalmak növekedésével, illetve a közmunkaprogramba történő magasabb beintegrálással lehet indokolni. 2017-re a 6\%os küszöbérték alá csökkent a térségben az álláskeresők aránya, ami napjainkra még alacsonyabb szintet mutat. Az országos adatok alapján a munkanélküliség 4 százalék alatti értékeket mutat. 


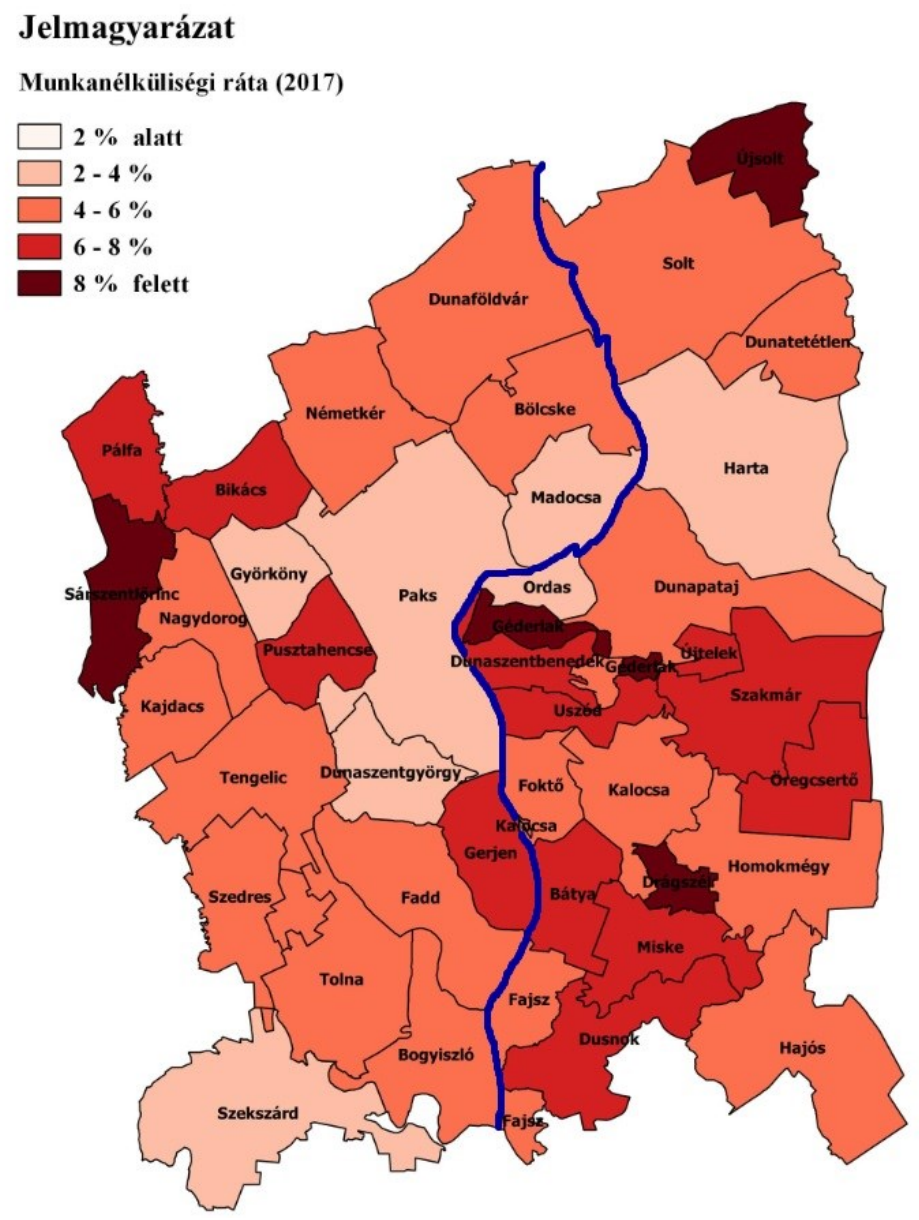

\section{7. ábra: A munkanélküliségi ráta mutató Paks és „gravitációs zónájában”, 2017-ben (százalék)}

Forrás: Országos Területfejlesztési és Területrendezési Információs Rendszer (TeIR) (Saját szerkesztésü infógrafika, QGIS; 2019)

A 7. ábrán Paks és ,gravitációs zónájában” lévő munkanélküliségi ráta arányszám látható, 2017-ben. A térségben kifejezetten magas Drágszél, Géderlak, Sárszentlőrinc és Újsolt települések tekintetében az álláskeresők száma. A lehatárolt térség négy járásszékhelyi ranggal rendelkező városában ez az érték jóval alacsonyabb, az országos átlaghoz közelít. Szembetűnő viszont, hogy Kalocsa körül egy ,gyürüt” alkotva a települési munkanélküliségi ráta $6 \%$ felett van. Így a térség periférikus településeit ezen ábra segítségével is jól le lehet határolni, miszerint a „gravitációs zóna” ÉNY-i térsége (Bikács, Pálfa, Sárszentlőrinc) mellett a Kalocsa közvetlen szomszédságában lévő településeken tapasztalható a munkanélküliségi ráta magas értéktartományban való tartózkodása. Kalocsa szerepe a térségben láthatóan erős, centrumként definiálható, hiszen a szolgáltatások, illetve munkaalkalmak magasabb arányban vannak jelen (így mutatva az alacsonyabb munkanélküliségi rátát), mint a környező településeken. Paks és közvetlen környezetében, alacsonyabb munkanélküliség tapasztalható, mint Kalocsa tekintetében, 2017-ben. Jól látható, hogy a Duna két oldalán fekvő települések képesek együtt mozogni egyes mutatók tekintetében. Ilyen mutatónak bizonyul a munkanélküliségi ráta is, hiszen közel azonos értékek tapasztalhatóak a térség északi részén fekvő Solt, illetve Dunaföldvár és Bölcske tekintetében, amely homogenizálódás az itt található Duna híd egyik következményeként magyarázható. 


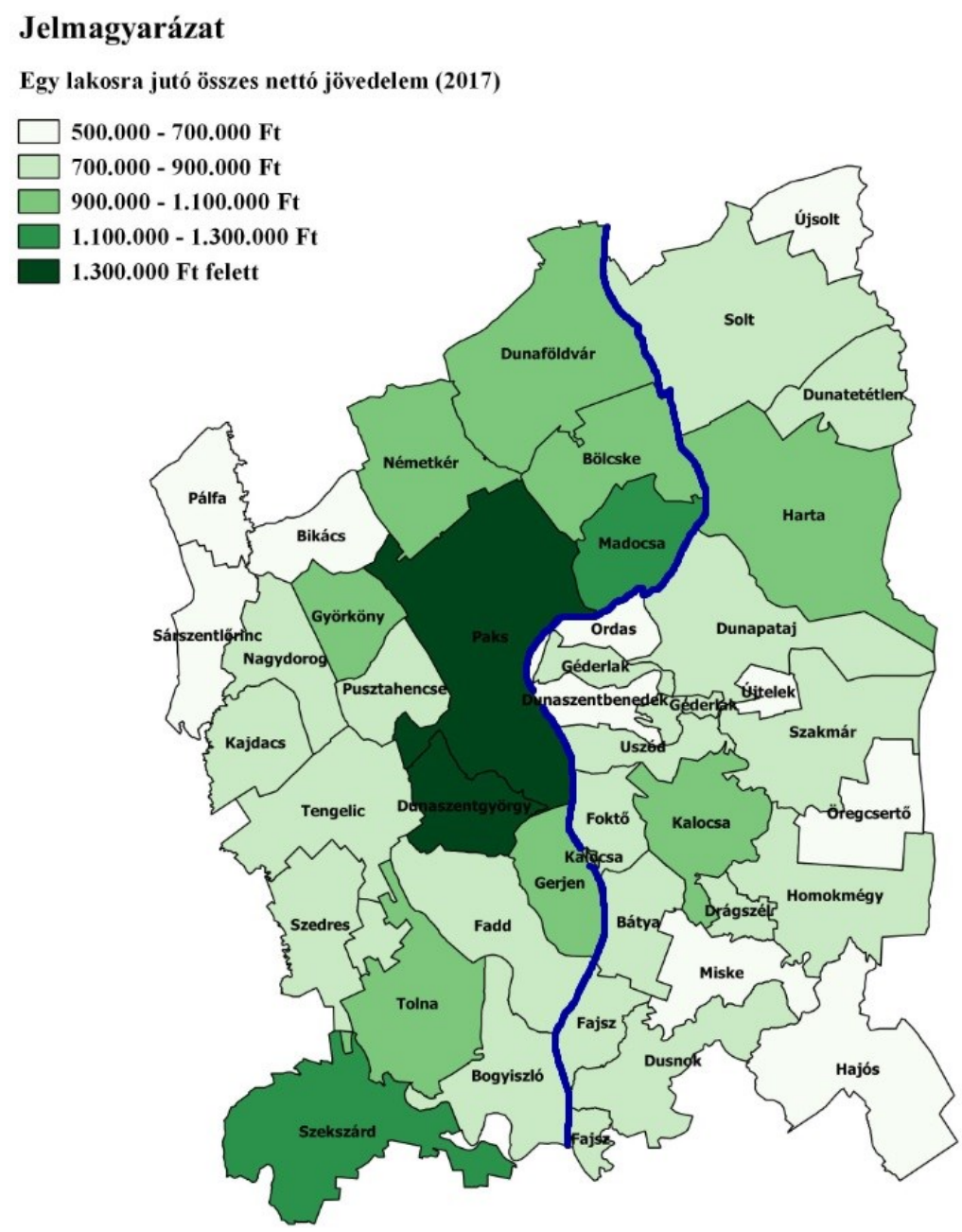

\section{8. ábra: Az egy lakosra jutó összes nettó jövedelem mértéke Paks és "gravitációs zónájában", 2017-ben (Ft)}

Forrás: Országos Területfejlesztési és Területrendezési Információs Rendszer (TeIR Helyzet-Tér-Kép) (Saját szerkesztésü infógrafika, QGIS; 2019)

A 8. ábrán a vizsgált települések egy före jutó összes nettó jövedelmének mértéke látható, 2017ben, ahol az összegek a teljes népesség arányában történtek kiszámításra. A jövedelmi egyenlötlenségeket látva az nem tünik meglepetésnek, hogy jóval alacsonyabb a munkanélküliségi ráta a gazdagabb településeken. A leggazdagabb települések tekintetében ez többnyire 4 százalék alatti munkanélküliséget takar, míg a legszegényebb területeken 8 százalék feletti a munkanélküliségi mutató. Az ábra alapján megállapítható, hogy a jövedelmi viszonyok Paks és közvetlen környezetében a legmagasabbak. Az országos átlagot, amely 1.043.113 Ft/fö, csupán öt település jövedelmi viszonyai haladják meg (Paks, Dunaszentgyörgy, Madocsa, Szekszárd, Györköny), amelyek közül négy Paks és közvetlen szomszédtelepülései közé tartozik, így tovább hangsúlyozva Paks centrumként történő szerepét a térségben.

Kalocsa kiemelt, centrum szerepét ezen ábra is tovább magyarázza, hiszen a jövedelmi viszonyok tekintetében magasabb értékeket mutat, mint közvetlen környezete, így hangsúlyozva a jövedelmi leszakadást a lehatárolt téregység Duna-Tisza közén lévő települések esetében. Ami viszont a Kalocsai járás összességét illeti, jóval elmarad Paks és „agglomerációja” értékeitől. 
Szembetűnő emellett, hogy periférikus területnek a térség ÉNY-i (Bikács, Pálfa, Sárszentlőrinc), illetve DK-i részén található települések (Hajós, Öregcsertő, Miske) alkotta területeket lehet minősíteni. Továbbá szükséges szemügyre venni a Kalocsai járás településeit, illetve az ott realizált értékeket, hiszen ezen értékek jóval elmaradnak az országos átlagtól, illetve a dunántúli területen fekvő településeken realizált jövedelmektől.

\section{Infrastrukturális mutatók „alrendszere”}

Az Infrastrukturális mutatók ,alrendszerben” elemzésre kerül az ezer före jutó személygépkocsik száma, illetve annak változása, az új építésü lakások aránya, illetve változása és a közműolló, amely a közcsatorna hálózatba bekapcsolt lakások arányaként írható fel a vezetékes ivóvízhálózatba bekapcsolt lakások százalékában, így igyekezvén információt nyújtani a Paks és „gravitációs zónájába” tartozó járásokról (LAU 1), illetve a téregység településeiről (LAU 2) egyaránt.

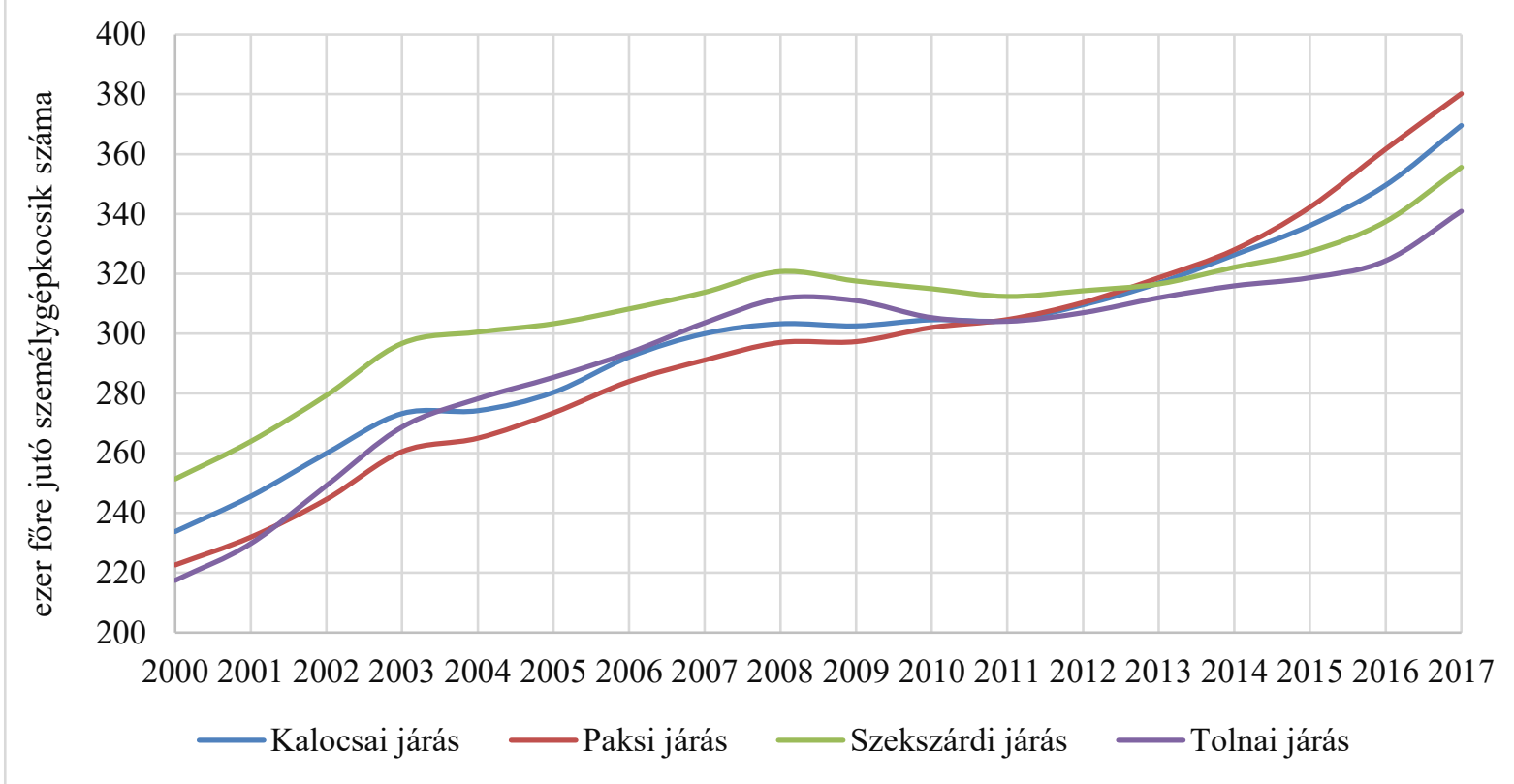

\section{9. ábra: Az ezer lakosra jutó személygépkocsik száma az év végén a Kalocsai, a Paksi, a Szekszárdi és Tolnai járásokban; 2000-2017 (ezrelék)}

Forrás: Országos Területfejlesztési és Területrendezési Információs Rendszer (TeIR) (Saját szerkesztésü diagram, 2019)

A 9. ábráról az ezer lakosra jutó személygépkocsik száma olvasható le az ezredfordulótól 2017ig terjedő intervallumban a Kalocsai, a Paksi, a Szekszárdi és Tolnai járásokban. Látható, hogy 2000 és 2008 között folyamatosan növekedett a személyautók száma, majd stagnálás, illetve kismértékü csökkenés tapasztalható. A 2017-es évig ismét növekedési szakaszt lehet megfigyelni. A vizsgált időszakon belüli változást figyelembe véve a Szekszárdi járáson kívül másfélszeres növekedés tapasztalható a másik három statisztikai járásban. E megállapítások alapján Paks centrumként történő definiálása teljes mértékben helytálló. A térség ÉNY-i részén fekvő települések (Pálfa, Pusztahencse, Sárszentlőrinc) esetében e mutatószámokat is alacsony értékhatárok között találjuk, ami periférikus területre enged következtetni.

Az új építésű lakások arányának változása látható a 10. ábrán, a lakásállományon belül a Kalocsai-, a Paksi-, a Szekszárdi- és a Tolnai járásokban. A lakásépítési kedv az ingatlanlétesítési árak megemelkedésével csökkenésnek indult a kétezres évek közepétől, 
viszont 2015-től kezdődően mind Tolnai, mind pedig a Szekszárdi járás esetében növekedésnek indult az elemzett mutatószám. Ami viszont igen szembetünő, hogy egyik járás tekintetében sem haladja meg a 0,4 \%-ot az új építésű lakások aránya (a lakásállományon belül) 2017-ben, ami a bázisévhez képest harmadára történő csökkenést jelent. Napjainkban országosan az ingatlanfejlesztés és építés ösztönzése magas szintet képvisel. Többek között a vállalkozások számára munkásszállók kialakítása és építése, illetve a családi házak létesítése is magas támogatottsági prioritást képvisel.

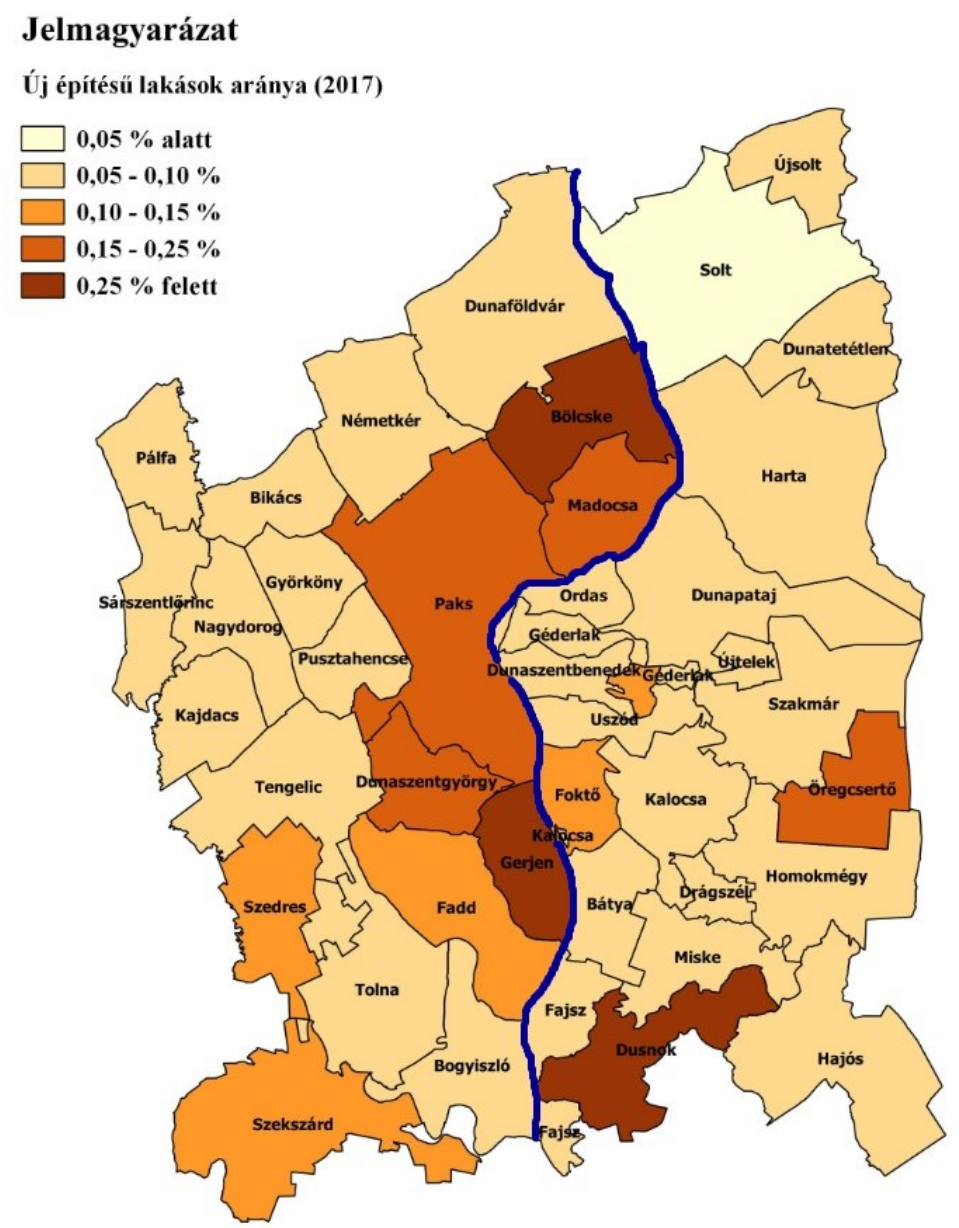

\section{0. ábra: 2017-ben épített lakások aránya Paks és „gravitációs zónájában”, a tárgyév végi lakásállományon belül (százalék)}

Forrás: Országos Területfejlesztési és Területrendezési Információs Rendszer (TeIR) (Saját szerkesztésü infógrafika, QGIS; 2019)

Az alacsony értékek közül kiemelkedő a térség dunántúli része, azon belül is Paks és a szomszédságába tartozó települések tekintetében, ahol többségében $0,15 \%$ feletti értékek figyelhetőek meg, illetve Dusnok és Öregcsertő települések tekintetében is átlag feletti az infógrafikán ábrázolt arányszám. 2017-ben a térség egyetlen települése sem haladja meg a 0,32 százalékos országos átlagot. Viszont, ha csak alacsony értéktartományban is, de mindenképpen szembetünő, hogy Paks és közvetlen szomszédtelepülései tekintetében nagyobb mértékben tapasztalható lakásépítése kedv 2017-ben, ezzel is elmélyítve a város centrum szerepét, viszont szükségesnek érzem megemlíteni, hogy Paks tekintetében az új építésü lakások számának csökkenése -valószínüleg - a beépíthető belterületek hiányának következménye. 
A 11. ábrán, a 2017-es adatok alapján kerül ábrázolásra a közmüolló aránya Paks és vonzáskörzetében. A térség közmühálózatának fejlettség mutatja, hogy a települések kétharmadában, köztük a négy járásszékhelyi város esetében is $80 \%$ feletti értékek olvashatóak le az infógrafikáról. Ellenben a vizsgált térség ÉNY-i része (Bikács, Györköny, Kajdacs, Németkér, Pálfa, Pusztahencse, Sárszentlőrinc), illetve Dunapataj, Ordas, Újsolt és Újtelek periférikus térségnek bizonyulnak. Itt 25\% alatti közmüvesítettségröl beszélhetünk a 2017-es adatok alapján.

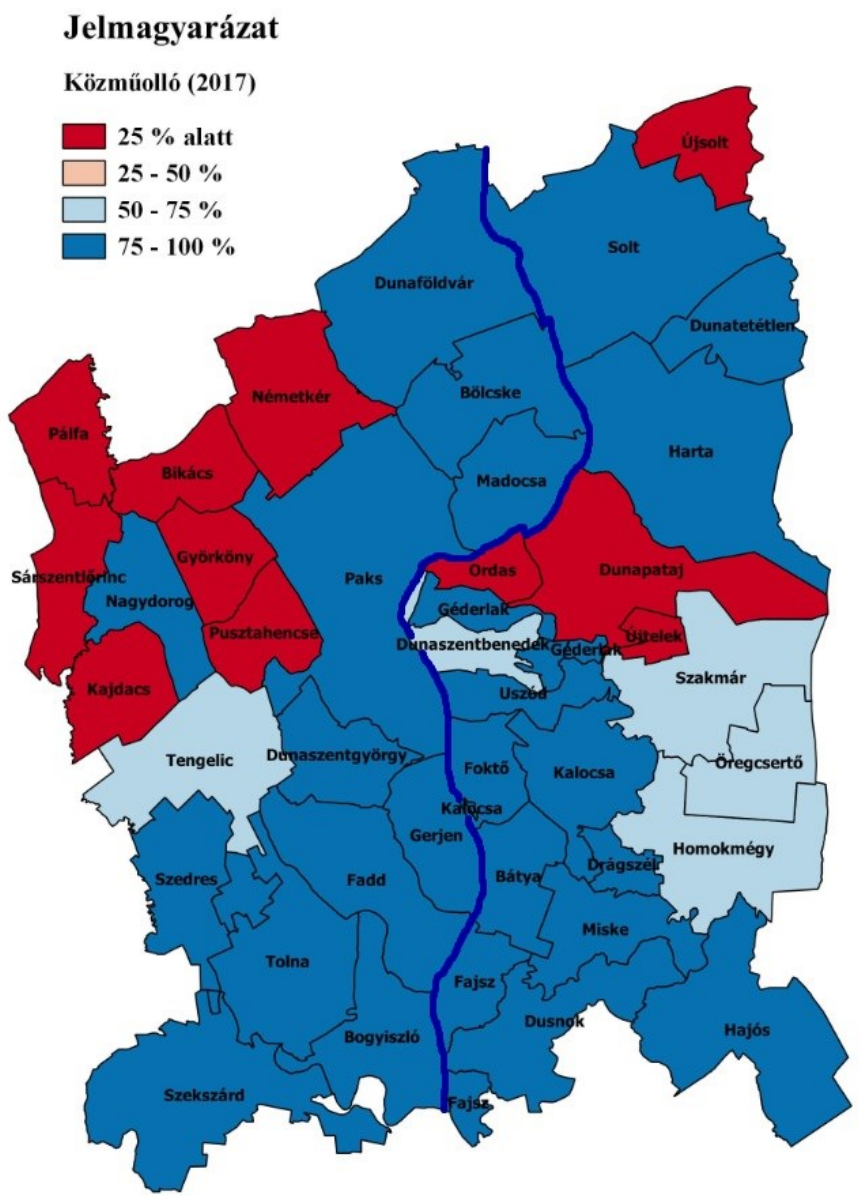

11. ábra: A közmúolló aránya Paks és ,gravitációs zónájában”, 2017-ben (\%)

Forrás: Országos Területfejlesztési és Területrendezési Információs Rendszer (TeIR) (Saját szerkesztésü infógrafika, QGIS; 2019)

A térség közmüolló szerinti ábrázolásánál szükségesnek érezzük megemlíteni, hogy a települések többségében, köztük a centrumként definiált településeken is az országos viszonylatban 85,5 százalékos közmüvesítettségi átlagértéket elérik.

\section{Összefoglalás}

A három „alrendszer” vizsgálata során számos hasonlóságot és eltérést is tapasztaltunk mind település, mind járási, mind pedig megyei és országos szinten. A társadalom elemzésénél a demográfia adatokat figyelembe véve kijelenthetö, hogy az országos trendekhez hasonlóan folyamatos népességfogyásról beszélünk Paks és ,gravitációs zónájával” a fókuszban. A népességszám változás tekintetében a Kalocsai járás települései magasabb értékeket mutatnak, mint a téregység dunántúli települései, ami a térség népességmegtartó képességének gyenge szintjét mutatja. Emellett ki kell emelni, hogy a lehatárolt térségen belül a négy járásszékhelyi 
ranggal rendelkező város (Kalocsa, Paks, Szekszárd és Tolna) nagy hányadát teszi ki a térség teljes népességéből, mi sem bizonyítja ezt jobban, mint többek között a magas népsürüségük, hiszen e négy városon kívül minden település 120 fö $/ \mathrm{km}^{2}$ alatti értékeket mutat. A természetes szaporodás/fogyás mutató esetében ki kell emelni, hogy a „gravitációs zóna” ÉNY-i, ÉK-i, illetve DK-i része 12 ezrelék alatti értékeket mutat, ezáltal a térség periférikus területeinek bizonyulnak. Továbbá szükséges megemlíteni, hogy a térség társadalma elöregedő státuszban van, hiszen az ezredfordulótól számítva rohamosan megnőtt a 60 évesnél idősebb lakosság aránya, kifejezetten Kalocsa és közvetlen környezetében.

A gazdasági ,alrendszer” mutatói alapján megállapítható, hogy a GDP részarányának emelkedése - többek között - az elmúlt tíz év gazdasági fellendülésének következménye. A munkanélküliségi ráta csökkenésével, így a munkaalkalmak számának növekedésével több munkaerőt képesek helyben foglalkoztatni. A lehatárolt terület elmaradottabb részeinek szintén az ÉNY-i, illetve Kalocsa és közvetlen szomszédtelepülései számítanak. Az egy lakosra jutó összes nettó jövedelem mértéke esetében megállapítható, hogy a jövedelmi viszonyok Paks és közvetlen környezetében a legmagasabbak, viszont szembetűnő emellett, hogy periférikus területnek a térség ÉNY-i, illetve DK-i részén található települések alkotta területeket lehet minősíteni.

Az infrastruktúra szempontjából a személygépkocsik számának növekedése, a közmüolló arányának növekedése, így „gravitációs zóna” településeinek magas közművesítettsége mindenképpen arra enged következtetni, hogy összességében a térség fejlödési pályán helyezkedik el. Ami valamelyest visszaveti az infrastrukturális ,alrendszer” fejlettségét az az új építésü lakások arányának alacsony száma. Viszont ezen alrendszer vizsgálatakor is megfigyelhetö, hogy a térség mely területei bizonyulnak centrumnak, illetve mely területei perifériának. Mindhárom mutató esetében a térség ÉNY-i része, a nyugati peremvidék, illetve Kalocsa és közvetlen környezete mutat fel alacsonyabb értékeket, így alátámasztva eddigi megállapításainkat, miszerint a „gravitációs zóna" földrajzi peremei viszonyulnak elmaradottabb térségnek.

\section{Irodalomjegyzék}

1. Barta, G. (1990). Centrum-periféria folyamatok a magyar gazdaság területi fejlődésében. In J. Tóth, Tér-Idő-Társadalom (old.: 170-190.). Pécs: MTA RKK.

2. Enyedi, G. (2000). Globalizáció a magyar területi fejlődésben. Tér és Társadalom, 110.

3. Enyedi, G. (2012). A város Történeti Arcai. In G. Enyedi, Városi Világ (old.: 29). Budapest: Akadémia Kiadó.

4. Faragó, L. (2016). Társadalmi-területi egyenlőtlenségek. Tér és társadalom, 118-123.

5. Farkas, Tibor; Bruder, Emese; Kolta, Dóra; Gerencsér, Ilona (2020): Diverse migration processes of rural youth and young adults in Hungary In: Schafft, Kai; Stanic, Sonja; Horvatek, Renate; Maselli, Annie (szerk.) Rural youth at the crossroads: Transitional societies in central Europe and beyond.

6. G. Fekete, É. (2006). Hátrányos helyzetből előnyök? Elmaradott térségek felzárkózásának esélyei az Észak-magyarországi régióban. Földrajzi közlemények, 55-66.

7. Horváth, G. (2004). Területi egyenlőtlenségek Európában. Magyar Tudomány, 962977.

8. Illés, I. (1997). Regionális politika Európában és Magyarországon. In I. Forgács, Jubileumi évkönyv 1996-2006 (old.: 119-141.). Budapest: NFH. 
9. Káposzta, J. (2010). A versenyképesség föbb összefüggései. In J. Káposzta, H. Nagy, M. Urbánné Malomsoki, K. Kollár, P. Goda, \& L. Péli, Regionális- és városgazdaságtan (old.: 34-43.). Gödöllö: SZIE RGVI.

10. Káposzta, J. (2014). Területi különbségek kialakulásának föbb összefüggései. Gazdálkodás, 399-412.

11. Káposzta, J.-Tóth, T. (2013). Centrum és periféria modellek. In J. Káposzta, \& T. Tóth, Regionális és vidékfejlesztési ismeretek. Debrecen: Debreceni Egyetemi Kiadó.

12. Központi Statisztikai Hivatal. (2000-2017). TSTAR adatok. Forrás: www.teir.hu

13. Központi Statisztikai Hivatal. (2017). TSTAR adatok. Forrás: TeIR - Helyzet-TérKép: https://www.teir.hu/helyzet-ter-kep/

14. Lengyel, I. (2000). A regionális versenyképességről. Közgazdasági szemle, 962-987.

15. Lengyel, I. (2003). Verseny és területi fejlödés: térségek versenyképessége Magyarországon. 454.

16. Lengyel, I.-Rechnitzer, J. (2004). Regionális gazdaságtan. Budapest-Pécs: Studia Regonum - Dialóg Campus Kiadó.

17. Miniszterelnökség. (2015. 06. 16.). A Paksi Társadalmi Tanács. Miniszterelnökségi határozat. Paks, Magyarország.

18. Nagyné Molnár M. (2013): Factors of success in case of local society. DETUROPE: CENTRAL EUROPEAN JOURNAL OF TOURISM AND REGIONAL DEVELOPMENT 5: 3 pp. 63-70.

19. Nagy Molnár M. -Lendvay E. (2018): New method to support decision making process in the local economic development of Hungary. REGIONAL STATISTICS 8: $2 \mathrm{pp}$. 69-91.

20. Nemes Nagy, J. (1995). A piacgazdasági átmenet regionális folyamatai.

21. Nemes Nagy, J. (1996). Centrumok és perifériák a piacgazdasági átmenetben.

22. Nemes Nagy, J. (1998). Tér a társadalomtudományban. Budapest.

23. Nemes Nagy, J. (2005). Fordulatra várva - a regionális egyenlőtlenségek hullámai. In Z. Dövényi, \& S. F., A földrajz dimenziói (old.: 141-158.). Budapest: MTA FKI.

24. Péli, L. (2010). A versenyképesség föbb összefüggései. In J. Káposzta, H. Nagy, M. Urbánné Malomsoki, K. Kollár, P. Goda, \& L. Péli, Regionális és városgazdaságtan (old.: 34-44.). Gödöllö: SZIE RGVI.

25. Péli, László; Neszmélyi, György Iván (2015): Territorial Differences Of Rural Cities And The Development Of Transport Infrastructure In Hungary. ROMANIAN REVIEW OF REGIONAL STUDIES: JOURNAL OF THE CENTRE FOR REGIONAL GEOGRAPHY 11: 2 pp. 69-84., 16 p. (2015)

26. Péli László (2013): Növekedési pólusok főbb regionális gazdaságtani összefüggéseinek vizsgálata Magyarországon Budapest, Magyarország: Agroinform Kiadó (2013) ISBN: 9789635029709

27. Rechnitzer, J. (1990). Szempontok az innovációk térbeli terjeddésének kutatásához. Tér és Társadalom, 48-62.

28. Rechnitzer, J. (1993). Az innovációk és a regionális politika. In K. Kovács, Település, gazdaság, igazgatás a térben (old.: 271-299.). Pécs: MTA RKK.

29. Rechnizter, J. (1994). A regionális gazdasági növekedés elméletei. In J. Rechnitzer, Fejezetek a regionális gazdaságtan tanulmányozásához (old.: 142-167.). Győr-Pécs: MTA RKK.

30. Ritter Krisztián (2008): A helyi fejlesztés esélyei - agrárfoglalkoztatási válság és területi egyenlötlenségek Magyarországon. Területi Statisztika 48. (5) pp. 554-572. ISSN 0018-782

31. Ritter, K. (2010): Socio-economic development and employment crisis in agriculture in Hungary. pp. 72-89. In: Kulcsár, L. (Ed.): Regional aspects of social and economic. 
32. Tóth Tamás (2018): Gazdaságfejlesztési lehetőségek a jól müködő településeken. STUDIA MUNDI - ECONOMICA 5: 1 pp. 59-67., 9 p. (2018) DOI: 10.18531/Studia.Mundi.2018.05.01.59-67

33. Tóth Tamás, Oláh Izabella (2019): Gondolatok a hazai településfejlesztésről a legkisebbek szemszögéből. STUDIA MUNDI - ECONOMICA 6: 1 pp. 93-103., 11 p. (2019) DOI: 10.18531/Studia.Mundi.2019.06.01.93-103 